\title{
Implementasi Kebijakan Peraturan Bupati Buton Selatan Nomor 4 Tahun 2016 Tentang Alokasi Dana Desa Pada Desa Lapandewa Kaindea
}

\author{
Rusli \\ Universitas Muhammadiyah Buton \\ Email: rusli.rusimm@gmail.com
}

\begin{abstract}
Abstrak, Implementasi Kebijakan Bupati Buton Selatan Nomor 4 Tahun 2016 tentang Alokasi Dana desa Pada Desa Lapandewa Kaindea. Penelitian ini bertujuan untuk mengetahuai Manfaat yang ditimbulkan dari kebijakan Bupati Buton Selatan Nomor 4 Tahun 2016 tentang Alokasi Dana Desa baik itu Pemerintah Desa maupun Masyarakat Desa. Penelitian ini menggunakan metode Deskriptif kualitatif, dimana penelitian ini bermaksud menyajikan suatu gambar yang terperinci tentang suatu situasi khusus, seting sosial, atau hubunga serta memberikan gambaran secara tepat sifat-sifat individu. Sumber Data Utama dalam penelitian ini adalah Wawancara, Informan, selebihnya adalah Data tambahan seperti Dokumen-dokumen, catatan, Laporanlapaoran maupun Arsip resmi. Implementasi Kebijakan Bupati Buton Selatan Nomor 4 Tahun 2016 tentang lokasil Dana Desa di Desa Lapandewa Kaindea dapat dikatakan belum Baik. Hal ini dilihat dari 2 indikator yaitu 1) Partisipasi, dimana Pemerintah Desa Lapandewa Kaindea belum sepenuhnya Melibatkan Masyarakat dalam pembahasan Alokasi Dana Desa, 2) Sumber Daya, Pemerintah Desa Lapandewa Kaindea dalam hal Sumber daya Aparat Desa sudah maksimal dalam Bekerja, tapi sebagian Aparat Desa belum sepenuhnya bekerja. Hasil Penelitian menunjukan bahwa 2 indikator pada Iplementasi Kebijakan Bupati Buton Selatan Nomor 4 Tahun 2016 tentang Alokasi Dana Desa did Desa Lapandewa Kaindea Belum Sepenuhnya melibatkan Masyarakat.
\end{abstract}

Kata Kunci: Implementasi, Anggaran Dana Desa 


\section{Pendahuluan}

Undang-Undang No. 6 Tahun 2014 tentang Desa maka desa memberi keleluasaan untuk menekankan prinsip-prinsip demokrasi, peran serta masyarakat, pemerataan, keadilan serta dengan memperhatikan potensi dan keanekaragaman desa. Undang-Undang ini sebagai landasan hukum bagi tiap desa untuk mengatur dan mengurus kepentingan masyarakat setempat menurut prakarsa sendiri berdasarkan aspirasi masyarakat. Masyarakat diberi peran yang lebih besar dalam pembangunan desa. Perencanaan dan implementasi pembangunan seharusnya merupakan usaha untuk memberdayakan rakyat sehingga mereka mempunyai akses terhadap sumbersumber ekonomi.

Model pembangunan yang melibatkan masyarakat dapat juga disebut dengan model pembangunan partisipatif. Pelaksanaan pembangunan partisipatif merupakan konsekuensi logis dari tuntutan reformasi dan keterbukaan yang diinginkan oleh masyarakat sejak tumbangnya rejim orde baru, yang juga didukung oleh prinsip-prinsip penyelenggaraan pemerintahan yang tertuang dalam Undang-Undang No. 6 Tahun 2014 tentang Desa yang mengamanatkan pentingnya dilaksanakan demokratisasi, partisipasi masyarakat. Desa diberikan kewenangan untuk menyelenggarakan pemerintahan dan pembangunan di tingkat desa.

Pembangunan yang cenderung mengarah pada sentralisasi kekuasaan dan pengambilan keputusan dari atas ke bawah (top-down) kini mulai diminimalkan, dan muncul konsep pembangunan alternatif yang menekankan pentingnya pembangunan berbasis masyarakat (community based development), yang bersifat bottom up dan menggunakan pendekatan lokalitas yaitu pembangunan yang menyatu dengan budaya lokal serta menyertakan partisipasi masyarakat lokal bukan memaksakan suatu model pembangunan dari luar (Zubaedi, 2007:10).

Berangkat dari undang-undang ini maka Desa mempunyai asas dan tujuan yaitu diberikan keleluasan untuk merancang dan mengatur arah kebijakan pemerintahan dan arah pembangunan di desa masing-masing sesuai dengan prinsip-prisip profesionalitas, efisien, efektif terbuka serta bertanggung jawab demi tercapainya masyarakat adil makmur dan sejahtera.Ini mengandung makna bahwa desa memiliki kewenangan untuk mengatur dan mengurus rumah tangganya sesuai dengan kewenangan asli maupun yang diberikan, yang menyangkut peranan pemerintah desa sebagai penyelenggara pelayanan publik di desa dan sebagai pendamping dalam proses perencanaan dan pelaksanaan pembangunan daerah yang melibatkan masyarakat di tingkat desa. Untuk melaksanakan kewenangan tersebut, pemerintah desa memiliki sumber-sumber penerimaan yang digunakan untuk membiayai kegiatan-kegiatan yang dilakukannya. Salah satu hal yang penting untuk diperhatikan dalam mendukung proses pelaksanaan pembangunan di setiap desa adalah adanya kepastian keuangan untuk pembiayaannya.

Selama ini, pembangunan desa masih banyak bergantung dari pendapatan asli desa dan swadaya masyarakat yang jumlah maupun sifatnya tidak dapat diprediksi. 
Oleh karena itu untuk menunjang pembangunan di wilayah pedesaan, pemerintah pusat mengarahkan kepada beberapa kabupaten untuk melakukan pengalokasian dana langsung ke desa dari APBD-nya. Kebijakan pengalokasian dana langsung ke desa ini disebut sebagai kebijakan Alokasi Dana Desa (ADD), Pemerintah pusat dalam Peraturan mentri dalam negeri Nomor 113 Tahun 2014 tentang pengelolaan keuangan Desa

Dalam Peraturan mentri dalam negeri Nomor 113 Tahun 2014 tentang Desa disebutkan bahwa bagian dari dana perimbangan pusat dan daerah yang diterima oleh kabupaten/kota untuk desa paling sedikit 10\% yang pembagiannya untuk setiap desa secara proporsional yang merupakan alokasi dana desa. Jadi, Alokasi Dana Desa (ADD) adalah dana yang dialokasikan oleh Pemerintah Kabupaten untuk desa, yang bersumber dari bagian dana perimbangan keuangan pusat dan daerah yang diterima oleh Kabupaten.

Namun demikian besaran anggaran yang diperoleh desa dalam melaksanakan pembangunan masih dalam berbagai macam masalah yaitu anatara lain kualitas kepemimpinan seorang kepala desa dalam hal ini perencanaan dan penyusunan arah pembanguna desa sehingga membuat terlambat dalam melakukan proses pembangunan di desa akibatnya seringkali desa terlambat untuk pencairan anggaran dana desa, kemudian gaya kepemimpinan seorang kepala desa yang kurang transparan dengan masyarakat sehingga masyarakat tidak terlibat dalam proses pembangunan di desa, kemudian tidak adanya transparansi anggaran Alokasi Dana Desa akibatnya tujuan dalam meciptakan desa yang adil makmur dan sejahtera belumlah tercapai.

Pelaksanaan Alokasi Dana Desa di Kabupaten Buton Selatan ini didasarkan pada realita bahwa sebagai pilar otonomi daerah, desa semakin membutuhkan pendanaan yang seimbang untuk menjalankan peran yang lebih kongkrit dalam pembangunan daerah. Pemerintah Kabupaten Buton Selatan berharap dengan adanya alokasi dana ke desa, perencanaan partisipatif berbasis masyarakat akan lebih berkelanjutan, karena masyarakat dapat langsung terlibat dalam pembuatan dokumen perencanaan di desanya dan ikut merealisasikannya.

\section{Metode Penelitian}

Tujuan penelitian itu adalah deskriptif Kualitatif, dimana penelitian ini bermakasud menyajikan suatu gambar yang terperinci tentang suatu situasi khusus, seting sosial atau hubungan serta memberikan gambaran secara tepat sifat-sifat individu. Teknik Pengambilan Sampel dilakukan secara purposive sampling, dimana sejumlah nama ditentukan berdasarkan representasi informasi yang ingin didapatkan untuk mendukung hasil dalam penelitian ini. Metode analisis utama yang digunakan dalam penelitian ini adalah analisis data kualitatif yang diartikan sebagai usaha analisis berdasarkan katakata yang disusun kedalam bentuk teks yang diperluas. Analisis data dilakukan secara deskriptif kualitatif yang bertujuan untuk membuat deskripsi secara sistematis, faktual, dan akurat mengenai fakta-fakta dan sifat-sifat dari fenomena yang diselidiki. 


\section{Hasil dan Pembahasan}

\section{Implementasi Kebijakan Bupati Buton Selatan}

APBN 2015 memiliki posisi yang penting dan unik karena diperuntukan untuk sebuah kebutuhan yang disusun pada tahun transisi pemerintahan dan yang pada peraturannya bersifat baseline budget, yaitu disusun hanya berdasarkan keutuhan pokok penyelenggaraan pemerintah dan pelayanan kepada masyarakat.Hal itu dimaksudkan untuk memberikan ruang gerak pemerintahan hasil Pemilu 2014 untuk melaksanakan program sesuai platform, visi, dan misi yang direncanakan. Tidak kalah pentingnya, Anggaran Pendapatan dan Belanja Negara (APBN) 2015 ini adalah tahun pertama dialokasikannya dana desa.Dana desa adalah dana yang bersumber dari APBN yang diperuntukkan bagi desa, yang ditransfer melalui anggaran belanja daerah kabupaten/kota. Dana ini digunakan untuk membiayai penyelenggaraan pemerintahan, pelaksanaan pembangunan, pembinaan kemasyarakatan, dan pemberdayaan masyarakat desa. Dana desa di alokasikan dari APBN berdasarkan Pasal 72 Ayat 1 Huruf b UU No 6/2014 tentang Desa.

Anggaran Belanja Negara Tahun Anggaran 2016 direncanakan sebesar Rp $2.039,5$ triliun, terdiri dari belanja pemerintah pusat Rp 1.392,4 triliun serta anggaran transfer kedaerah dan dana desa sebesar Rp 646,96 triliun. Anggaran transfer kedaerah direncanakan sebesar Rp 637,9 triliun dan dana desa direncanakan sebesar Rp 9,06 triliun atau 0,44 persen dari total belanja APBN 2015.

Prinsip Dasar Keseluruhan Pelaksanaan kebijakan Bupati di Desa Lapandewa Kaindea tidak boleh dipahami hanya sebagai suatu proses yang dilakukan secara Administarasi Formal dan Mekanisme Prosedural, Namun yang penting adalah dinamika proses dari Pelaksanaan Kegiatan Dalam pelaksanaan Alokasi Dana Desa. Dalam Hal ini, seluruh Pihak yang Terkait pada Pelaksanaan sistem diharapkan senantiasa mampu mengambil keputusan dan malaksanakan kegiatan yang lebih adil. Berpihak pada Masyarakat miskin, jujur, lebih berorientasi pada kemandirian dan pembangunan berkelanjuta.

Berkaiatan dengan penelitian tentang Implementasi Kebijakan Bupati Buton Selatan Nomor 4 Tahun 2016 Tentang Alokasi Dana Desa studi kasus Desa Lapandewa Kaindea Kecamatan Lapandewa.ada 2 indikator yang penulis sajikan yaitu:

\section{Partisipasi}

Salah satu pilar dari tatakelola pemerintahan yang baik adalah keterlibatan para pemangku kepentingan. Dalam konteks pengelolaan dana desa ini, dalam memenuhi prinsip tatakelola pemerintahan yang baik, masyarakat desa perlu terlibat dalam pelaksanaan anggaran dana desa.

Keterlibatan masyarakat dalam pengelolaan dana desa dapat dilakukan melalui musyawarah desa yang merupakan forum permusyawaratan yang diikut oleh Badan 
Permusyawaratan Desa, pemerintah desa, dan unsur masyarakat desa untuk memusyawaratkan hal yang bersifat strategis dalam penyelenggaraan pemerintahan desa.

Aspirasi masyarakat diserap, ditampung, dihimpun, dan ditindak lanjuti oleh Badan Permusyawaratan Desa. Badan Permusyawaratan Desa berhak mengawasi dan meminta keterangan tentang penyelenggaraan pemerintahan desa kepada pemerintah desa. Mereka juga berhak menyatakan pendapat atas penyelenggaraan pemerintahan desa, pelaksanaan pembangunan desa, pembinaan kemasyarakatan desa, dan pemberdayaan masyarakat desa. Hak mengawasi dan meminta keterangan tentang penyelenggaraan pemerintahan desa, termasuk di dalamnya pengawasan terhadap alokasi dana desa yang bersumber dari APBN, sesuai dengan ketentuan yang diatur dalam UU No 6/2014 tentang Desa.

Dari paparan di atas dapat disimpulkan bahwa implementasi alokasi dana desa dalam APBN 2016 perlu mendapat pengawasan dan partisipasi masyarakat agar alokasi dana desa yang baru di inisiasi dalam APBN tahun 2015 ini transparan, akuntabel, dan berorientasi pada kepentingan masyarakat desa. Hanya dengan begitu, ia membawa dampak bagi peningkatan kesejahteraan masyarakat desa. Namun dalam sejumlah wawancara yang dilakukan, proses penetapan ADD melalui proses yang demokratis, seperti pelibatan masyarakat dalam rapat pengambilan keputusan adalah tidak pernah dilakukan.

Untuk mewujudkan hal itu, tahap pelaksanaan kegiatan adalah ; a.) Pendekatan yang mementingkan dialog dengan masyarakat, b.) analisis dan metode dan metode perencanaan secara partisipatori berdasarkan kemampuan dan kebutuhan masyarakat, c.) metode formulasi kebijakan yang mendukung pelaksanaan kegiatan pembangunan.

Dalam hal ini Implementasi Kebijakan bukan hanya menyangkut pembahasan yang tertulis namun pada tahap Pelaksanaan dimasyarakat. Hasil Wawancara dengan Bapak La Harami yang juga Sekretaris Desa Lapandewa Kaindea mengatakan. Bahwa mengenai implementasi kebijakan bupati buton selatan nomor 4 itu sudah seharusnya terimplementasi dengan baik karena itu mrngandung tanggung jawab besar terhadap Daerah.

\section{Sumber Daya}

Hingga tahun 2016, kita telah berada dalam fase pelaksanaan anggaran untuk APBN 20116. Pelaksanaan anggaran adalah fase ketika segala sumber pendanaan APBN di implementasikan sesuai dengan arah kebijakan, termasuk kebijakan transfer kedaerah dan dana desa. Alokasi APBN untuk dana desa menjadi pos pendapatan bagi keuangan desa dengan mengefektifkan program yang berbasis desa secara merata dan berkeadilan. Alokasi dana desa diharapkan dapat membawa dampak pada peningkatan kesejahteraan masyarakat, terutama dalam memperkuat upaya untuk mendorong pertumbuhan ekonomi yang makin merata. 
Mengingat APBN 2015 merupakan tahun pertama dialokasikannya dana desa, penting bagi kita untuk bersama-sama mengawasi pelaksanaan anggaran tersebut. Hal ini sejalan dengan pendapat Salvatore Schiavo-Campo dan Daniel Tommasi dalam Managing Government Expenditure (Asian Development Bank, 1999) sasaran kunci manajemen keuangan publik terbagi menjadi empat kategori (categories of public expenditure management objectives), yakni dimensi ekonomi/finansial, dimensi manajemen, dimensi kepentingan publik, dan dimensi politik. Pengawasan dana desa yang mulai dialokasikan dalam APBN 2015 ini dapat kita pandang dari dimensi kepentingan publik. Sasaran kunci manajemen keuangan publik dari dimensi kepentingan publik berupa transparansi, akuntabilitas, dan orientasi pada kepentingan masyarakat.

Sisi transparansi menghendaki bahwa dana APBN dialokasikan secara jujur dan terbuka. Transparansi anggaran dilakukan antara lain dengan meningkatkan kualitas dokumentasi anggaran yang menggambarkan tujuan alokasi dana desa dan bagaimana dana tersebut digunakan. Sedangkan dalam, sisi akuntabilitas mengandung pengertian bagaimana alokasi dana desa ini disalurkan dalam bentuk barang dan jasa untuk kepentingan umum. Akuntabilitas dana desa tidak semata-mata bagaimana dana ini tersalurkan kemasyarakat desa, tetapi lebih jauh lagi adalah bagaimana dana desa bermanfaat bagi masyarakat desa. Sisi akuntabilitas juga menitikberatkan pada pertanggung jawaban dana desa yang pada hakikatnya berasal dari kontribusi warga Negara dalam membiayai pengeluaran Negara melalui pembayaran pajak.

Sisi orientasi terhadap masyarakat terkandung maksud bahwa alokasi dana desa didesain memenuhi tujuan pemberdayaan desa agar menjadi kuat, maju, mandiri, dan demokratis. Dengan begitu, ia diharapkan dapat menciptakan landasan yang kuat dalam melaksanakan pemerintahan dan pembangunan di desa. Masyarakat desa jadi sasaran utama dalam manajemen alokasi dana desa ini. Karena itu, pemanfaatan dana desa hendaknya memfasilitasi adanya partisipasi dan interaksi masyarakat desa di dalamnya hingga manfaatnya sampai kepada masyarakat desa, baik langsung maupun tidak langsung. Dari Prinsip Akuntabel dan Transparan Maka bagaimana Kemudian Pelaksanaan dimasyarakat.

Untuk mendukung deskripsi tersebut, dalam beberapa wawancara terungkap data bahwa implementasi untuk kebijakan Bupati Buton Selatan Nomor 4 itu sudah terimplentasi dengan baik terbukti dengan Anggaran Dana Desa yang telah mampu memberikan sumbangsi untuk pembangunan diseluruh indonesia khususnya di desa Lapandewa kaindea walaupun kemudian kemarin, ADD untuk tahap I Desa Lapandewa Kaindea untuk tahap satu menagalami keterlambatan yang seharusnya bulan maret sudah pencairan tapi nanti bulan juni baru kemudian kita dicairkan karena kesibukan keuangan di daerah untuk desa Lapandewa Kaindea pada tahun 2016 secara keseluruhan mendapat Rp. 412. 315.000. dari anggaran yang ada ini kemudian dibagi menjadi 4 item yaitu ; 1. Penyelenggaraan Pemerintah Desa sebanyak 60 \%, 2. 
Penyelenggaraan pembangunan Desa sebanyak $20 \%$, 3. Bidang Pemberdayaan Masyarakat sebanyak 5 \%, dan 4. Bidang Pembinaan Kemasyarakatan sebnyak 15 \%.

Dari Hasil Wawancara tersebut Nampak bahwa ada dua hal yang dapat di defenisikan yaitu transparansi bahwa anggaran yang di peroleh sebanyak itu dan yang selanjutanya adalah dari sekian anggaran yang di peoleh dari negara maka sekian persen untuk bagian Pembangunan. Selain itu, sumberdaya juga berkaitan dengan kompetensi pegawai lingkup Pemerintah Desa Lapandewa Kaindea dalam hal sumber daya para aparat Desa sudah maksimal dalam bekerja, tapi sebagian aparat desa belum sepenuhnya bekerja.

\section{Disposisi}

Disposisi dalam hal ini adalah Watak dan Karakter yang dimilikoleh implementor, seperti komitmen, kejujuran, sifat demokratis. Apabila implementor memiliki disposisi yang baik . Maka dia dapat menjalankan kebijakan dengan baik seperti apa yang di inginkan oleh pembuat kebijakan. Faktor watak / atau sikap pelaksana yang dimiliki impelementor harus dapat mendukung dan melakasnakan setiap kegiatan. Karena tanpa dukungan watak / sikap pelaksana yang baik maka kegiatan tersebut dapat di implementasikan dengan baik. Dalam pelaksanaan kegiatan sosialisasi dan rembug kesepakatan masyarakat yang dilaksanakan ditngkat desa sesuai dengan jadwal yang telah ditentukan sebelumnya melalui undangan maupun pembertahuan secara informal kepada masyarakat.

Dalam hasil wawancara terdapat data yang menunjukan bahwa dari semua program Alokasi Dana Desadalam hal ini Pemerintah Desa Kurang menunjukan kepedulian terhadap Pelaksanaan Kegiatan Kepemudaan. Karena tanpa kepedulian dari pelaksana maka kegiatan kegiatan kepemudaan tidak dapat di implementasikan dengan baik.

\section{Struktur Birokrasi}

Struktur organisasi yang bertugas mengimplenetasikan kebijakan memiliki pengaruh yang signifikan terhadap implementasi kebijakan. Salah satu dari aspek struktur yang penting dari setiap organisasi adalah adanya prosedur operasi yang standar ( standard operating prosedures atau SOP ). SOP menjadi pedoman bagi setiap implementor dalam bertindak. Struktur organisasi yang terlalu panjang akan cenderung melemahkan pengawasan dan menimbulkan red-tape, yakni prosedur birokrasi yang rumit dan kompleks. Ini pada gilirannya menyebabkan aktifitas organisasi yang tidak fleksibel.

Sebelum pengorganisasian Masyarakat dilakukan beberapa kegiatan dalam rangka merealisasikan Alokasi Dana Desa, yakni refleksi Kemiskinan dan Pembangunan serta pemetaan swadaya, refleksi kemiskinan guna mendorong masyarakat mampu merefleksi masalah kemiskinan di Desa Lapandewa Kaindea dan terutama menimbulkan kesadaran kritis warga bahwa akar persoalan kemiskinan berkaitan erat 
dengan lunturnya nilai-nilai universal kemanusiaan ( aspek moral ), prinsip kemasyarakatan (aspek good governance) dan pembanguna berkelanjutan (aspek tridaya ). Pelaksana dari kegiatan ini adalah perangkat desa dan seluruh masyarakat. Adapun hasil yang diharapkan dari kegiatan ini adalah tumbuhnya kesadaran kritis masyarakat bahwa akar persoalan kemiskinan karena lunturnya nilai-nilai luhur kemanusiaan. Prinsip kemasyarakatan dan prinsip pembangunan berkelanjutan dan tumbuhnya kesadaran bahwa upaya penangulangan kemiskinan harus dimulai dari diri sendiri melalui perubahan mentaldan perilaku kolektif.

Merujuk pada sejumlah wawancara tmpak bahwa kurangnya keinginan pemerintah desa dalam merefleksi pemberdayaan terhadap Masyarakat. Kepala Pemerintah desa Alokasi Dana Desa dalam rumusan pemerintah sekarang ini fokus pada pelaksanaan penyelenggaraan pemerintahan dan penyelenggaraan pembangunan namun tetap ada juga untuk porsi anggaran untuk pemberdayaan dan pembinaan terhadap Masyarakat.

Pemerintah Desa selaku implemetor Kebijakan Bupati Buton Selatan hanya melakukan refleksi kegiatan pembangunan. Dalam segala hal kegiatan pembangunan dalam hal ini Alokasi Dana Desa harus melibatkan seluruh unsur Masyarakat di Desa Lapandewa Kaindea. Sedang yang nantinya menjadi pelaku dalam proses implementasi Kebijakan Bupati Buton Selatan Nomor 4 tentang Alokasi Dana Desa ada keingina untuk ikut terlibat sehingga fokcus group discusson untuk refleksi kemiskinan dan pembangunan menjadi upaya membangun paradigma baru terhadap penanggualangan kemiskinan dan pembangunan yang dihadapi bersama berkaitan dengan sikap/perilaku dan cara pandang masyarakat selama ini. Melalui serangkaian Kegiatan Masyarakat akan menumbuhkan kesadaran masyarakat saat ini dan membangun kesepakatan kondisi ideal yang akan dicapai. Hasil dari kegiatan ini akan mampu menetapkan kriteria pembangunan kebutuhan riil masyarakat. Hasil wawancara dengan bapak La ucu

Dengan adanya Alokasi Dana Desa, desa dapat mempercepat pembanguna disegala bidang jadi Alokasi DanaDesa sangat membantu yang dulunya kepala-kepala dusun tidak digaji namun dengan pemerintah mengeluarkan kebijakn tentang ADD ini dapat gaji sehingga kepala-kepala dusun juga semangat untuk melakukan pekerjaan mereka, serta adanya pemberitahuan pembangunan jalan rabat beton, inialah gunanya Alokasi Dana Desa, yang sebelumnya tidak ada anggaran untuk jalan rabat beton tapi dengan adanya Alokasi Dana Desa pembangunan itu akan berjalan. Kebijakan Bupati Buton Selatan Nomor 4 tahun 2016 Tentang Alokasi Dana Desa dalam hal ini adalah pemerintah Desa Lapandewa Kaindea. Hal ini yang dilakukan pemerintah desa selaku implementor adalah melakukan refleksi kepemimpinan moral. 


\section{Kesimpulan}

Berdasarkan deskripsi diatas bahwa Implementasi Kebijakan Bupati Buton Selatan Nomor 4 Tahun 2016 studi kasu di Desa Lapandewa Kaindea, yaitu; 1) Proses pembangunan dari Alokasi Dana Desa di Desa Lapandewa Kaindea belum dilaksanakan dengan baik itu nampak dengan kebingungannya masyarakat dengan adanya Dana Alokasi Dana Desa tetapi Pembangunan di Desa Lapandeawa Kaindea tidak ada sehingga memunculkan ketidak percayaan masyarakat terhadap kinerja Pemerintah Desa. 2) Komunikasi yang dilakukan kepada Masyarakat, kemudia tranparasi terhadap anggaran itu sangat mempengaruhi keterlibatan Masyarakatsehingga proses pembangunan itu tidak tercapai. 3) Tidak berjalannya kontrol terhadap pemerintah desa.

\section{Daftar Pustaka}

Arikunto S, 2006, Prosedur Penelitian Suatu Pendekatan Praktek, Rieke Cipta, Jakarta.

Ariesto Hadi Sutopo dan Adrianus Arief, 2010. Judul : Terampil Mengolah Data Kualitatif Dengan NVIVO. Penerbit Prenada Media Group : Jakarta.

Kartasasmita. Ginanjar, 1995, Pemberdayaan Mayarakat; Sebuah Tinjauan Administrasi, Pidato Pengukuhan Jabatan Guru Besar Dalam Ilmu Administrasi Universitas Brawijaya, Malang, 27 Mei.

Moleong, 2006, Metode Penelitian Kualitatif, Remaja Redoskarya. Bandung.

Moenir,H.A.S., 2002, Manajemen Pelayanan Umum di Indonesia, Jakarta, Bumi Aksara.

Silalahi, Ulber, 2009, Metode Penelitian Sosial, Refika Aditama, Bandung.

Subarsono, AG. Analisis Kebijakan Publik. Yogyakarta: Pustaka Pelajar. 2005

Sugiyono, MPA, 2004. Metode Penelitian Administrasi, Edisi Ke-13. CV Alavabeta,

Bandung

Tangkilisan, Hessel Nogi. S. Implementasi Kebijakan Publik. Jakarta: Lukman Offset.2003.

Tangkilisan, Hessel Nogi. S. Kebijakan Publik Yang Membumi. Jakarta: Lukman Offset.2003.

Peraturan Pemerintah Nomor 72 Tahun 2005 tentang Desa.

Peraturan Bupati Buton Selatan Nomor 4 Tahun 2016 tentang Alokasi Dana Desa.

Surat Edaran Menteri Dalam Negeri Nomor 140/60/SJ Tahun 2005 tentang Pedoman

Alokasi Dana Desa dari Pemerintah Kabupaten/Kota kepada Pemerintah Desa.

Peraturan Mentri Dalam Negeri Nomor 113 Tahun 2014 Tentang Pengelolaan Keuangan Desa.

Peraturan Mentri Dalam Negeri Nomor 114 Tahun 2014 Tentang Pedoman Pembangunan Desa.

Undang-Undang Nomor 23 Tahun 2014 tentang Pemerintahan Daerah.

Undang-Undang Nomor 6 Tahun 2014 tentang Desa. 